\title{
Genetic architecture of prostate cancer in the Ashkenazi Jewish population
}

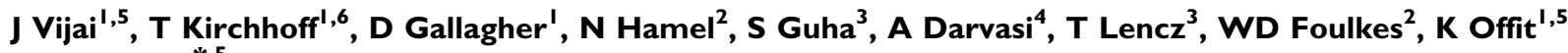 \\ and RJ Klein*,5
}

'Clinical Genetics Service, Department of Medicine, Memorial Sloan-Kettering Cancer Center, New York, NY I0065, USA; ${ }^{2}$ Program in Cancer Genetics, Departments of Oncology and Human Genetics, McGill University; and Research Institute of the McGill University Health Center, Montreal, Quebec H2W IS6, Canada; ${ }^{3}$ Department of Psychiatry, Division of Research, The Zucker Hillside Hospital Division of the North Shore - Long Island Jewish

Health System, Glen Oaks, NY I 1004, USA; ${ }^{4}$ The Institute of Life Sciences, The Hebrew University of Jerusalem, Jerusalem 91904, Israel; ${ }^{5}$ Program in Cancer Biology and Genetics, Memorial Sloan-Kettering Cancer Center, 1275 York Avenue, Box 337, New York, NY I0065, USA

BACKGROUND: Recently, numerous prostate cancer risk loci have been identified, some of which show association in specific populations. No study has yet investigated whether these single nucleotide polymorphisms (SNPs) are associated with prostate cancer in the Ashkenazi Jewish (AJ) population.

METHODS: A total of 29 known prostate cancer risk SNPs were genotyped in 963 prostate cancer cases and 613 controls of AJ ancestry. These data were combined with data from 124I additional Ashkenazi controls and tested for association with prostate cancer. Correction for multiple testing was performed using the false discovery rate procedure.

RESULTS: Ten of twenty-three SNPs that passed quality control procedures were associated with prostate cancer risk at a false discovery rate of 5\%. Of these, nine were originally discovered in studies of individuals of European ancestry. Based on power calculations, the number of significant associations observed is not surprising.

CONCLUSION: We see no convincing evidence that the genetic architecture of prostate cancer in the AJ population is substantively different from that observed in other populations of European ancestry.

British Journal of Cancer (201 I) I 05, 864-869. doi:I0.1038/bjc.20II.307 www.bjcancer.com

Published online 9 August 201 I

(c) 201 I Cancer Research UK

Keywords: SNPs; prostate cancer; association studies

Recent studies have identified numerous single nucleotide polymorphisms (SNPs) that modify an individual's risk of developing prostate cancer (Amundadottir et al, 2006; Eeles et al, 2008; Gudmundsson et al, 2007a; Gudmundsson et al, 2008; Gudmundsson et al, 2007b; Haiman et al, 2007; Robbins et al, 2007; Thomas et al, 2008). Although some investigators have considered the possibility of heterogeneity between ethnic groups, where a SNP shows a different effect on prostate cancer risk depending on the population being studied, these studies only considered ethnic groups with different continents of ancestral origins (Haiman et al, 2007; Waters et al, 2009; Yamada et al, 2009; Hooker et al, 2010; Zheng et al, 2010). As alleles of numerous SNPs are known to vary in frequency across Europe (Bersaglieri et al, 2004), and population substructure is consistently observed in Americans with ancestry from different locations in Europe (Price et al, 2008; Tian et al, 2008), there is a possibility that prostate cancer risk alleles may have different effects in different populations of European ancestry.

*Correspondence: Dr RJ Klein; E-mail: kleinr@mskcc.org

${ }^{6}$ Current address: NYU Cancer Institute, New York University, New York, NY 10016, USA

Received 5 April 201।; revised 29 June 201।; accepted II July 20 II; published online 9 August 2011
Ashkenazi Jews are Jews whose ancestors come primarily from central and eastern Europe; the majority of North American Jews and a large proportion of Israeli Jews are of Ashkenazi ancestry. The global linkage disequilibrium (LD) profiles of the Ashkenazi Jewish (AJ) population do not seem to differ significantly from that of other populations of European ancestry. However, it has been suggested that there may be significant local differences in allele frequencies and haplotype structure between the Ashkenazi population and other European populations, including at loci associated with common cancer (Gold et al, 2008; Olshen et al, 2008; Price et al, 2008; Tian et al, 2008). Therefore, examination of known prostate cancer risk SNPs in the AJ population provides a unique opportunity to test for genetic heterogeneity at these loci among individuals of European ancestry.

Here, we report the results of a case-control association study in the AJ population of 29 previously identified prostate cancer SNPs. Our data argue against the hypothesis that risk alleles for prostate cancer generally have different effects in the Ashkenazi and non-Ashkenazi European ancestry populations.

\section{MATERIALS AND METHODS}

Case and control DNA samples were obtained under IRB-approved protocols. Specifically for the samples from the Israeli blood bank, 
corresponding institutional review boards and the National Genetic Committee of the Israeli Ministry of Health approved the studies. The DNA samples from 963 prostate cancer cases were used in this study. Of these, 885 cases presented at Memorial Sloan-Kettering Cancer Center (MSKCC) with histologically confirmed prostate cancer and report all four grandparents were from Eastern Europe and Jewish. An additional 78 cases from Montreal, a Canadian metropolitan area, for whom both parents were of Ashkenazi ancestry were included. These patients were treated for prostate cancer at one of the three McGill University affiliated hospitals: the Royal Victoria and Montreal General Hospital sites of the McGill University Health Center and the Jewish General Hospital. Control DNA was collected from 1854 healthy men in New York and Israel - 419 participants in New York Cancer Project (Mitchell et al, 2004), 194 samples from the National Laboratory for the Genetics of Israeli Populations (NLGIP) (www.tau.ac.il/medicine/NLGIP/nlgip.htm), and 1241 healthy individuals from the Israeli Blood Bank. All controls selfreport that all four grandparents are of Ashkenazi ancestry. These samples have been previously described (Kirchhoff et al, 2004; Shifman et al, 2008; Tischkowitz et al, 2008). The cases range in age from 26 to 94 (mean 68, s.d., 8.3). The controls range in age from 18 to 98 (mean 46, s.d., 15.2).

A total of 29 SNPs of interest were identified based on previous reports of association with prostate cancer risk from recent genome-wide association studies (GWAS) and other studies (Table 1). Most of these SNPs were selected on the basis of being reported in one of the GWAS papers as being significantly associated with prostate cancer risk. We also included numerous SNPs at $8 \mathrm{q} 24$ that were discovered in follow-up studies of this locus after its initial identification by linkage and association. Finally, we also included a SNP (rs7008482) reported as a prostate cancer risk SNP in the African-American population to see if this SNP had an effect in the Ashkenazi population despite not being associated in other European populations studied.

Samples from MSKCC, McGill University, the NY Cancer Project, and the NLGIP were genotyped using the Sequenom
MassArray technology at MSKCC. This includes all cases and 31\% of the controls. We designed two multiplex assays to genotype all 29 SNPs using Assay Design software (Sequenom, San Diego, CA, USA). PCR amplification and extension were performed using Sequenom iPLEX Gold reagents as per the manufacturer's protocol and analysed on the Sequenom MassARRAY system (Sequenom). Genotypes were called using the Typer 4.0 software package (Sequenom).

For quality control on the Sequenom data, we first manually inspected the cluster plots. Then, the data was processed with PLINK (Purcell et al, 2007). In all, 112 individuals with more than $20 \%$ missing data were removed. All SNPs had $<20 \%$ missing data and showed no significant deviation from Hardy-Weinberg equilibrium in controls $(P>0.01$; Table 2$)$. Six SNPs had significant differences in genotype calling rate between cases and controls $(P<0.01 ; \mathrm{FDR}<0.05)$ and were therefore removed from further consideration.

The controls from the Israeli blood bank were processed separately as they were initially genotyped genome wide as part of a separate study not related to cancer. These samples were fully anonymised immediately after collection and subsequently genomic DNA was extracted from blood samples by using the Nucleon kit (GE Healthcare, Piscataway, NJ, USA). The samples were genotyped on the Illumina HumanOmni1-Quad arrays (Illumina, San Diego, CA, USA) according to manufacturer's specifications under protocols approved by the Institutional Review Board of the North Shore-LIJ Health System. SNPs were filtered on the following bases: call rate $<98 \%$, minor allele frequency $<0.02$ and Hardy-Weinberg exact test $P<0.000001$. The samples were filtered based on cryptic identity and first- or second-degree relatedness using pairwise identity-by-decent (IBD) estimation (PI_HAT >0.20) in PLINK with 128403 LD pruned $\left(r^{2}>0.2\right)$ genome-wide SNPs and population stratification using Principal Component Analysis with Ancestry Informative Markers specific for the AJ population.

Of the 23 SNPs that passed quality control from the Sequenom genotyping, 20 were directly genotyped on the Illumina chip. The

Table I Known prostate cancer risk SNPs successfully tested in this study

\begin{tabular}{|c|c|c|c|c|c|c|}
\hline SNP & Chr. & Gene & Alleles (Maj/Min) & MAF & Prev. OR & Citation \\
\hline rs721048 & 2 & EHBPI & G/A & 0.19 & 1.15 & Gudmundsson et al (2008) \\
\hline rs2660753 & 3 & CHMP2B;POUIFI & $\mathrm{C} / \mathrm{T}$ & 0.11 & 1.18 & Eeles et al (2008) \\
\hline rs9364554 & 6 & SLC22A3; SLC22A2; LPAL2; LPA & $\mathrm{C} / \mathrm{T}$ & 0.29 & 1.17 & Eeles et al (2008) \\
\hline rs 10486567 & 7 & $J A Z F I$ & G/A & 0.23 & 0.74 & Thomas et al (2008) \\
\hline rs6465657 & 7 & LMTK2; BHLHB8 & $\mathrm{T} / \mathrm{C}$ & 0.46 & 1.12 & Eeles et al (2008) \\
\hline rs7008482 & 8 & - & $\mathrm{T} / \mathrm{G}$ & 0.83 & 1.8 & Robbins et al (2007) \\
\hline rs 1016343 & 8 & - & $\mathrm{C} / \mathrm{T}$ & 0.18 & 1.37 & Eeles et al (2008) \\
\hline rs 13254738 & 8 & - & $\mathrm{A} / \mathrm{C}$ & 0.34 & l. I | & Haiman et al (2007) \\
\hline rs 16901979 & 8 & - & C/A & 0.031 & 1.79 & Gudmundsson et al (2007a) \\
\hline rs6983267 & 8 & - & $\mathrm{G} / \mathrm{T}$ & 0.50 & 0.8 & Yeager et al (2007) \\
\hline rs7000448 & 8 & - & $\mathrm{C} / \mathrm{T}$ & 0.39 & 1.14 & Haiman et al (2007) \\
\hline rs4242382 & 8 & - & G/A & 0.12 & $1.4 \mid$ & Thomas et al (2008) \\
\hline rs4242384 & 8 & - & $\mathrm{A} / \mathrm{C}$ & 0.09 & 1.88 & Eeles et al (2008) \\
\hline rs7920517 & 10 & MSMB & G/A & 0.48 & 0.82 & Eeles et al (2008) \\
\hline rs 10993994 & 10 & $M S M B$ & $\mathrm{~T} / \mathrm{C}$ & 0.60 & 0.8 & Eeles et al (2008) \\
\hline rs4962416 & 10 & CTBP2 & $\mathrm{T} / \mathrm{C}$ & 0.27 & 1.2 & Thomas et al (2008) \\
\hline rs793।342 & $1 \mid$ & - & $\mathrm{G} / \mathrm{T}$ & 0.49 & 0.84 & Eeles et al (2008) \\
\hline rs 10896449 & $1 \mid$ & - & $G / A$ & 0.48 & 0.78 & Thomas et al (2008) \\
\hline rs4430796 & 17 & TCF2 & G/A & 0.49 & 1.24 & Gudmundsson et al (2007b) \\
\hline rs7501939 & 17 & TCF2 & $\mathrm{C} / \mathrm{T}$ & 0.42 & 0.83 & Gudmundsson et al (2007b) \\
\hline rs|859962 & 17 & - & $\mathrm{G} / \mathrm{T}$ & 0.54 & 0.8 & Gudmundsson et al (2007b) \\
\hline rs2735839 & 19 & $K L K 2 ; K L K 3$ & G/A & 0.15 & 0.83 & Eeles et al (2008) \\
\hline rs5945572 & $x$ & NUDTI I; NUDTIO & G/A & 0.35 & 1.24 & Gudmundsson et al (2008) \\
\hline
\end{tabular}

Abbreviations: alleles = major/minor alleles; chr. = chromosome; gene = nearby gene as reported in the cited literature; MAF=allele frequency in the controls of the cited paper for the minor allele as observed in the Ashkenazi Jewish population; prev. OR=previous odds ratio for the SNP as cited by the given paper; SNP=single nucleotide polymorphism. When MAF is $>0.5$, it indicates that the minor allele in the Ashkenazi Jewish population is the major allele in the study that initially reported the SNP. 
Table 2 Genotype counts and deviation from Hardy-Weinberg equilibrium stratified by disease status and source study

Genotype counts (Hardy-Weinberg $P$ )

\begin{tabular}{|c|c|c|c|c|c|c|c|}
\hline SNP & $\begin{array}{c}\text { Alleles } \\
\text { (Maj/min) }\end{array}$ & $\begin{array}{l}\text { MAF in } \\
\text { controls }\end{array}$ & MSKCC controls & $\begin{array}{l}\text { NLGIP } \\
\text { controls }\end{array}$ & $\begin{array}{l}\text { Israeli blood } \\
\text { bank controls }\end{array}$ & MSKCC cases & Montreal cases \\
\hline rs721048 & G/A & 0.14 & $7 / 99 / 303(1)$ & $2 / 46 / 112(0.37)$ & $30 / 299 / 912(0.36)$ & $21 / 214 / 575(0.79)$ & $2 / 1 \mid / 51(0.19)$ \\
\hline rs2660753 & $\mathrm{C} / \mathrm{T}$ & 0.24 & $27 / 156 / 226(I)$ & | 4/50/95 (0.084) & 69/445/727 (0.94) & $57 / 297 / 456(0.35)$ & $|/ 2| / 42(0.67)$ \\
\hline rs9364554 & $\mathrm{C} / \mathrm{T}$ & 0.19 & |0/| | 7/282 (0.72) & 10/55/95 (0.66) & $51 / 386 / 804(0.59)$ & $32 / 272 / 506(0.59)$ & $5 / 19 / 40(0.28)$ \\
\hline rs|0486567 & G/A & 0.29 & $42 / 143 / 224(0.013)$ & |2/57/9| (0.53) & $|12 / 513 / 6| 4(0.73)$ & 60/342/408 (0.34) & $5 / 24 / 34(0.75)$ \\
\hline rs6465657 & $\mathrm{T} / \mathrm{C}$ & 0.41 & $77 / 188 / \mid 42(0.31)$ & $34 / 82 / 44(0.75)$ & $200 / 578 / 459(0.44)$ & $165 / 386 / 259(0.35)$ & $13 / 27 / 24(0.31)$ \\
\hline rs7008482 & $\mathrm{T} / \mathrm{G}$ & 0.38 & $68 / 179 / 160(0.14)$ & $22 / 64 / 7 \mid(0.22)$ & $175 / 598 / 464(0.47)$ & $104 / 339 / 346(0.16)$ & $5 / 21 / 38(0.49)$ \\
\hline rs 1016343 & $\mathrm{C} / \mathrm{T}$ & 0.19 & $10 / 130 / 269(0.25)$ & 6/47/107 (0.79) & $48 / 372 / 819(0.46)$ & $38 / 282 / 489(0.84)$ & $3 / 23 / 38(1)$ \\
\hline rs| 3254738 & $\mathrm{~A} / \mathrm{C}$ & 0.41 & $64 / 204 /|4|(0.54)$ & 29/70/6I (0.25) & $218 / 572 / 447(0.14)$ & $153 / 425 / 232(0.10)$ & $9 / 34 / 21(0.60)$ \\
\hline rs 16901979 & C/A & 0.04 & I/34/374 (0.55) & $0 / 10 / 147(1)$ & ND & $1 / 62 / 748(1)$ & $0 / 8 / 55(1)$ \\
\hline rs6983267 & $\mathrm{G} / \mathrm{T}$ & 0.50 & $96 / 207 / 104(0.77)$ & $36 / 82 / 42(0.87)$ & $318 / 615 / 305(0.82)$ & | 68/39|/249(0.52) & $12 / 27 / 25(0.43)$ \\
\hline rs7000448 & $\mathrm{C} / \mathrm{T}$ & 0.48 & $90 / 203 / 116(1)$ & $39 / 85 / 36(0.53)$ & $279 / 606 / 34 I(0.77)$ & $234 / 380 / 191(0.14)$ & $|6 / 26 / 2|(0.21)$ \\
\hline rs4242382 & $\mathrm{G} / \mathrm{A}$ & 0.065 & I/62/345 (0.49) & $0 / 14 / 146(1)$ & 4/150/1087 (0.81) & 8/125/677 (0.38) & $0 / 5 / 59(1)$ \\
\hline rs4242384 & $\mathrm{A} / \mathrm{C}$ & 0.062 & |/57/35| (0.7|) & $0 / 12 / 148(1)$ & ND & $5 / 118 / 687(1)$ & 0/5/59 (I) \\
\hline rs7920517 & G/A & 0.45 & $81 / 194 / 132(0.55)$ & $42 / 75 / 41(0.53)$ & $250 / 605 / 386(0.65)$ & I50/392/268 (0.77) & $12 / 33 / 19(0.80)$ \\
\hline rs 10993994 & $\mathrm{~T} / \mathrm{C}$ & 0.50 & $97 / 202 / 109(0.84)$ & 46/77/35 (0.87) & $305 / 634 / 301$ (0.46) & $184 / 396 / 229(0.62)$ & 13/34/17 (0.80) \\
\hline rs49624I6 & $\mathrm{T} / \mathrm{C}$ & 0.33 & 46/I93/I70 (0.5I) & | 8/78/64 (0.49) & $|33 / 5| 6 / 59 \mid(0.21)$ & $95 / 344 / 370(0.27)$ & 6/25/33 (0.76) \\
\hline rs7931342 & $\mathrm{G} / \mathrm{T}$ & 0.33 & 46/173/185 (0.57) & 20/7I/69 (0.86) & 149/533/556 (0.23) & $69 / 319 / 422(0.44)$ & 6/29/29(1) \\
\hline rs 10896449 & G/A & 0.34 & $52 / 175 /|8|(0.38)$ & 20/72/68 (0.86) & I55/542/543 (0.28) & $76 / 321 / 4||(0.27)$ & 6/29/29 (1) \\
\hline rs4430796 & G/A & 0.43 & $69 / 206 / 134(0.54)$ & $35 / 76 / 49$ (0.63) & $225 / 607 / 392(0.73)$ & I83/397/230 (0.67) & $11 / 35 / 18(0.46)$ \\
\hline rs7501939 & $\mathrm{C} / \mathrm{T}$ & 0.44 & $82 / 206 / 121$ (0.77) & 29/77/52 (I) & $222 / 6 \mid 4 / 390(0.49)$ & $131 / 395 / 283(0.77)$ & $13 / 31 / 19(1)$ \\
\hline rs| 859962 & $\mathrm{G} / \mathrm{T}$ & 0.47 & $99 / 189 / 121(0.14)$ & $27 / 89 / 41(0.11)$ & ND & I57/392/262 (0.67) & $14 / 36 / 14(0.45)$ \\
\hline rs2735839 & G/A & 0.18 & 8/II9/28। (0.37) & $8 / 42 / 110(0.18)$ & $50 / 372 / 818(0.36)$ & $30 / 210 / 570(0.058)$ & $3 / 22 / 39(1)$ \\
\hline rs5945572 & G/A & 0.25 & 97/5/307 (NA) & $47 / 2 / 110$ (NA) & 303/0/936 (NA) & 244/2/563 (NA) & 17/0/47 (NA) \\
\hline
\end{tabular}

Abbreviations: $\mathrm{MAF}=$ minor allele frequency; $\mathrm{min}=$ minor; maj = major; MSKCC = Memorial Sloan-Kettering Cancer Center; NA = not applicable $(X$-chromosome SNP and all male study); ND = not done (no data is available on the Illumina chip for these individuals); NLGIP= National Laboratory for the Genetics of Israeli Populations; SNP= single nucleotide polymorphism. Genotype counts are given as minor homozygote/heterozygote/major homozygote.

remaining three SNPs were analysed only with the data from the Sequenom genotyping. Association analysis was performed in PLINK using logistic regression. Regression was performed twice, once without an adjustment for age and once with an adjustment for age of either diagnosis (cases) or sample collection (controls). Multiple testing was accounted for by holding the false discovery rate to be $5 \%$ using the Benjamini-Hochberg procedure (Benjamini and Hochberg, 1995).

To compute the power to detect association for each SNP, we assumed the previously reported odds ratio (OR), allele frequencies in our control population, and a sample size based on the number of successfully genotyped cases and controls. We used a previously reported method to compute the power at a significance level of 0.05 (Klein, 2007).

As a reference population of non-Ashkenazi white Americans, we used the GWAS data from the CGEMS Prostate Cancer GWAS Stage 1 - PLCO (phs000207.v1.p1) in dbGaP (http://www.ncbi. nlm.nih.gov/gap), removing duplicate individuals. To test for the heterogeneity of the OR between the CGEMS data and our data, we used the Breslow-Day test as implemented in PLINK.

\section{RESULTS}

In the current study, we genotyped 29 SNPs previously reported as being associated with prostate cancer risk in 963 AJ prostate cancer cases and $613 \mathrm{AJ}$ controls. The overall genotype call rate (fraction of genotypes for which a call is made) was $95 \%$. After quality control (QC) filtering the Sequenom data as described in the methods, resulting in 23 SNPs that pass QC, we added data from $20 \mathrm{SNPs}$ in 1241 male AJ controls genotyped with the Illumina Omni-1 Quad platform. As some controls came from Israel and some from the United States, we first queried if we observed allele frequency differences between AJ controls based on origin. Although two SNPs showed nominal differences in allele frequencies (rs9364554 and rs4242384; $P<0.05$ ), neither of these differences were significant after correcting for multiple testing. We were also concerned that the use of different genotyping platforms could lead to errors in our results. To test for this, we compared allele frequencies between individuals genotyped on the Illumina and Sequenom platforms and observed no differences (all nominal $P>0.3$ ).

We tested for association in 875 cases and 1810 controls total under an additive model. Before adjusting for age, 12 SNPs were nominally associated with prostate cancer risk $(P<0.05$; Table 3$)$. Of these, 10 were significant at a false discovery rate of $5 \%$. Among the 12 significant SNPs, only one - rs7008482 - shows a direction of effect opposite from that which was previously reported. As the SNP was identified in a case-control study of African-American men, we queried what effect this SNP had in the stage 1 data from the CGEMS prostate cancer GWAS of white Americans (Yeager et al, 2007). Although not significantly associated with risk $(P=0.2)$, this SNP has the same direction of effect that we observe in the Ashkenazi population $(\mathrm{OR}=0.92 ; 95 \% \mathrm{CI}=0.81-1.04)$. We next queried whether adjusting for age would influence these results. After removing 26 individuals without age information and adjusting for age as a covariate, nine SNPs were nominally significant $(P<0.05)$, of which three are significant at a false discovery rate of $5 \%$ (Table 3 ). Notably, seven SNPs are nominally significant both with and without age adjustment.

We next wished to query if we could observe any heterogeneity between the effect size we observed in the Ashkenazi population and the effects observed in other populations of European ancestry. To do so in a systemised way, we used the stage 1 CGEMS data. There are 18 SNPs that we tested here that are also present in the CGEMS data. Of these, only one (rs4962416) shows heterogeneity $(P=0.002)$. Although this SNP is associated with prostate cancer risk in the CGEMS stage 1 study $(\mathrm{OR}=1.3 ; 95 \%$ $\mathrm{CI}=1.2-1.5)$, we observe no evidence for association in the $\mathrm{AJ}$ population $(\mathrm{OR}=1.0 ; 95 \% \mathrm{CI}=0.9-1.1)$.

For several of the SNPs, we did not replicate the association with prostate cancer risk observed in a number of prior studies (Kim 
Table 3 Association of known prostate cancer risk SNPs in the Ashkenazi Jewish population

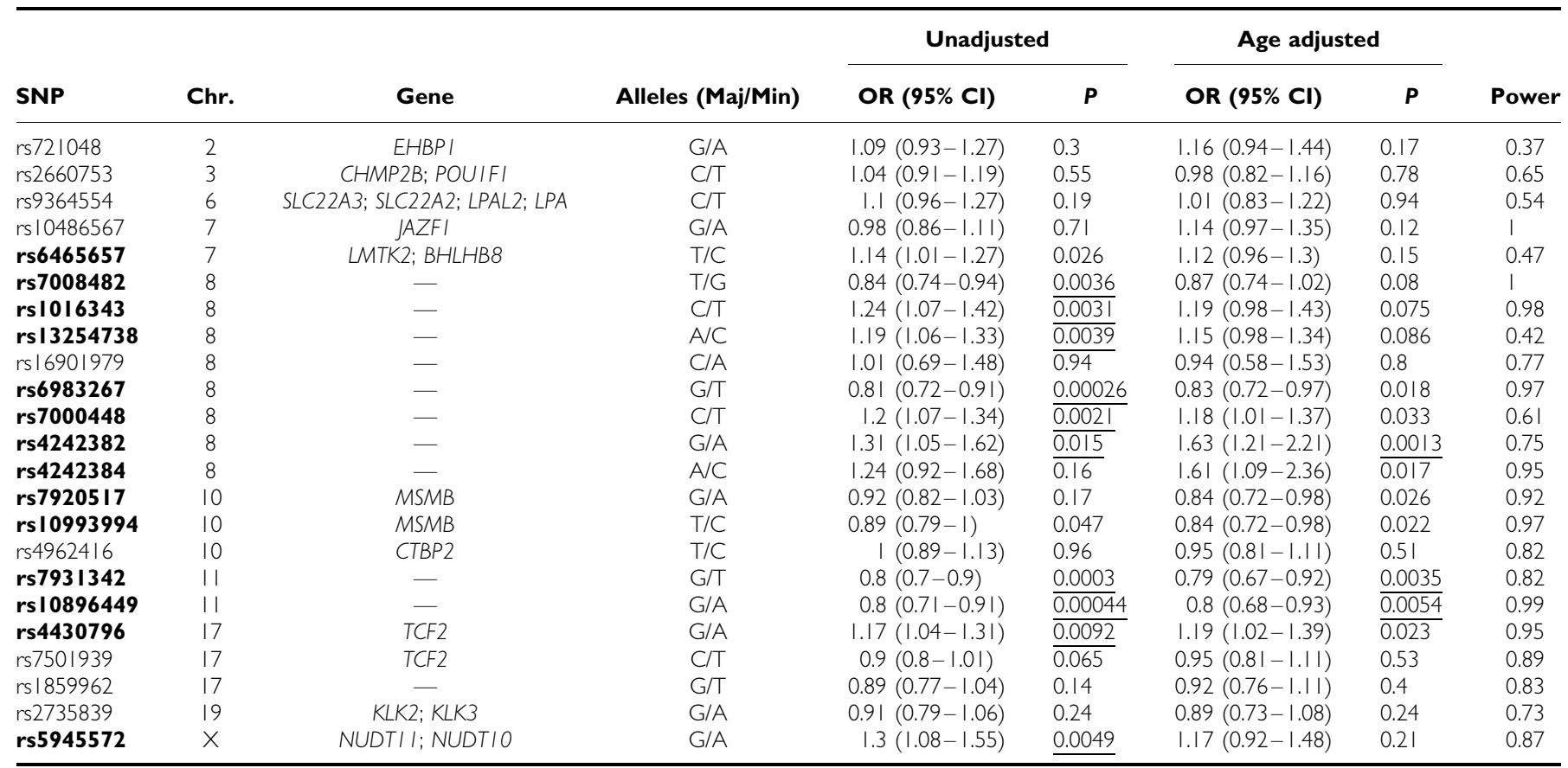

Abbreviations: alleles = major/minor alleles; Chr.= chromosome; gene= nearby gene as reported in the cited literature; min = minor; maj $=$ major; OR = odds ratio for the minor allele; SNP = single nucleotide polymorphism; $95 \% \mathrm{Cl}=95 \%$ confidence interval. SNPs in bold are significant at a nominal $P<0.05$ either without age adjustment, with age adjustment or both. Underlined $P$-values are significant at a false discovery rate of $5 \%$

et al, 2010). We note that the minor allele frequencies (MAF) at most of these SNPs in controls differ by at least 5 percentage points between the original report and our AJ individuals, and for seven SNPs the MAFs differ by at least 10 percentage points. As these differences in MAF could influence our power to replicate the previous findings, we computed the power using initially observed ORs from prior studies for each SNP along with the MAF observed in the AJ controls. We found that out of the nine SNPs for which we do not observe association with prostate cancer risk, our power to detect an association ranges from 37 to $99 \%$; there is $>80 \%$ power to detect association at four of these SNPs (Table 3). We next queried if we would expect to find 12 or fewer significant associations by chance given the computed powers. In 10000 simulations, given the computed power, we expect to find 12 or fewer significant associations $16 \%$ of the time.

\section{DISCUSSION}

Here, in the AJ population, we have replicated the association with prostate cancer risk for many of the prostate cancer risk SNPs tested. Overall, the effect of these SNPs in the AJ population is similar to that previously reported with the discovery of the SNPs. However, there are some SNPs for which we did not replicate the previously reported association despite having adequate power to do so. One potential explanation is the 'winner's curse', in which the first report of an association overestimates the magnitude of effect, leading to an inflated power estimation. In fact, for rs10486567, our estimate of $99 \%$ power was based on an OR of 0.74 as initially reported (Thomas et al, 2008). A more recent replication study suggests a more modest effect size of 0.84 , which would result in only $80 \%$ power to detect the association in the present study (Prokunina-Olsson et al, 2010). Another possible explanation is that a previously reported risk SNP is truly not associated with prostate cancer in the AJ population, either due to differences in linkage disequilibrium patterns or the absence of the functional variant in the AJ population. This may explain the lack of association between rs16901979 and prostate cancer in the AJ population, as the observed OR for this rare SNP was 1.0 in our study.

Of the significant results, only one SNP - rs7008482 - showed a different direction of effect than that which has been previously reported. This SNP was first identified as a prostate cancer risk allele in the African-American population (Robbins et al, 2007). In a well-powered study of Japanese men, no evidence for association between this SNP and prostate cancer was observed (Yamada et al, 2009). Similarly, despite being present on the genome-wide genotyping chips used in several prostate cancer GWAS, this SNP was never reported as being associated with prostate cancer in European populations (Eeles et al, 2009; Gudmundsson et al, 2009; Yeager et al, 2009), though it does have the same direction of effect in the CGEMS stage 1 data (white American individuals) as we observe in the Ashkenazi population. As the direction of effect is opposite from that previously reported, more studies will be needed to determine if this is a real prostate cancer risk SNP, perhaps tagging different functional alleles in different populations, or represents a false positive finding. Fine mapping this locus in the AJ and African-American populations could help shed light on this question.

Of the 18 SNPs also present in the CGEMS Stage 1 data set, only one (rs4962416) showed a significant heterogeneity of the OR between the CGEMS study and our AJ study. This SNP does not appear to be associated with prostate cancer in the AJ population. Although other SNPs appear to have ORs near 1, the weak effect of these SNPs in the initial reports makes it difficult to determine if these SNPs are truly not associated in the AJ population, illustrating population heterogeneity, or that our sample size is simply not large enough. Larger studies in which we are well powered to replicate the known prostate cancer associations will be necessary to answer this question. Furthermore, our sample size is likely too small to distinguish more subtle differences in the ORs between the populations.

We used controls from both the United States and Israel. Although we have previously found that $\mathrm{AJ}$ individuals from these two countries cluster similarly using principal components analysis (Gold et al, 2008), we nevertheless tested each SNP for 
allele frequency differences between Israeli and United States controls. As we did not find any significant difference, we do not think this is a major source of potential error in our study.

These results provide evidence of some differences in the genetic architecture of prostate cancer between the AJ population and other populations of European ancestry. However, these few differences are not enough evidence to argue that there are substantive differences in genetic susceptibility to prostate cancer between these populations. Further study of the genetics of prostate cancer in this unique population will be needed to understand to what extent genetic risk to prostate cancer is similar to that in other European populations and to what extent it is different.

\section{REFERENCES}

Amundadottir LT, Sulem P, Gudmundsson J, Helgason A, Baker A, Agnarsson BA, Sigurdsson A, Benediktsdottir KR, Cazier JB, Sainz J, Jakobsdottir M, Kostic J, Magnusdottir DN, Ghosh S, Agnarsson K, Birgisdottir B, Le Roux L, Olafsdottir A, Blondal T, Andresdottir M, Gretarsdottir OS, Bergthorsson JT, Gudbjartsson D, Gylfason A, Thorleifsson G, Manolescu A, Kristjansson K, Geirsson G, Isaksson H, Douglas J, Johansson JE, Balter K, Wiklund F, Montie JE, Yu X, Suarez BK, Ober C, Cooney KA, Gronberg H, Catalona WJ, Einarsson GV, Barkardottir RB, Gulcher JR, Kong A, Thorsteinsdottir U, Stefansson $\mathrm{K}$ (2006) A common variant associated with prostate cancer in European and African populations. Nat Genet 38(6): $652-658$

Benjamini Y, Hochberg Y (1995) Controlling the false discovery rate: a practical and powerful approach to multiple testing. J R Statist Soc B 57: $289-300$

Bersaglieri T, Sabeti PC, Patterson N, Vanderploeg T, Schaffner SF, Drake JA, Rhodes M, Reich DE, Hirschhorn JN (2004) Genetic signatures of strong recent positive selection at the lactase gene. Am J Hum Genet 74(6): $1111-1120$

Eeles RA, Kote-Jarai Z, Al Olama AA, Giles GG, Guy M, Severi G, Muir K, Hopper JL, Henderson BE, Haiman CA, Schleutker J, Hamdy FC, Neal DE, Donovan JL, Stanford JL, Ostrander EA, Ingles SA, John EM Thibodeau SN, Schaid D, Park JY, Spurdle A, Clements J, Dickinson JL, Maier C, Vogel W, Dork T, Rebbeck TR, Cooney KA, Cannon-Albright L, Chappuis PO, Hutter P, Zeegers M, Kaneva R, Zhang HW, Lu YJ, Foulkes WD, English DR, Leongamornlert DA, Tymrakiewicz M, Morrison J, Ardern-Jones AT, Hall AL, O'Brien LT, Wilkinson RA, Saunders EJ, Page EC, Sawyer EJ, Edwards SM, Dearnaley DP, Horwich A, Huddart RA, Khoo VS, Parker CC, Van As N, Woodhouse CJ, Thompson A, Christmas T, Ogden C, Cooper CS, Southey MC, Lophatananon A, Liu JF, Kolonel LN, Le Marchand L, Wahlfors T, Tammela TL, Auvinen A, Lewis SJ, Cox A, FitzGerald LM, Koopmeiners JS, Karyadi DM, Kwon EM, Stern MC, Corral R, Joshi AD, Shahabi A, McDonnell SK, Sellers TA, Pow-Sang J, Chambers S, Aitken J, Gardiner RA, Batra J, Kedda MA, Lose F, Polanowski A, Patterson B, Serth J, Meyer A, Luedeke M, Stefflova K, Ray AM, Lange EM, Farnham J, Khan H, Slavov C, Mitkova A, Cao G, Easton DF (2009) Identification of seven new prostate cancer susceptibility loci through a genome-wide association study. Nat Genet 41(10): 1116-1121

Eeles RA, Kote-Jarai Z, Giles GG, Olama AA, Guy M, Jugurnauth SK, Mulholland S, Leongamornlert DA, Edwards SM, Morrison J, Field HI, Southey MC, Severi G, Donovan JL, Hamdy FC, Dearnaley DP, Muir KR, Smith C, Bagnato M, Ardern-Jones AT, Hall AL, O'Brien LT, Gehr-Swain BN, Wilkinson RA, Cox A, Lewis S, Brown PM, Jhavar SG, Tymrakiewicz M, Lophatananon A, Bryant SL, Horwich A, Huddart RA, Khoo VS, Parker CC, Woodhouse CJ, Thompson A, Christmas T, Ogden C, Fisher C, Jamieson C, Cooper CS, English DR, Hopper JL, Neal DE, Easton DF (2008) Multiple newly identified loci associated with prostate cancer susceptibility. Nat Genet 40(3): 316-321

Gold B, Kirchhoff T, Stefanov S, Lautenberger J, Viale A, Garber J, Friedman E, Narod S, Olshen AB, Gregersen P, Kosarin K, Olsh A, Bergeron J, Ellis NA, Klein RJ, Clark AG, Norton L, Dean M, Boyd J, Offit K (2008) Genome-wide association study provides evidence for a breast cancer risk locus at 6q22.33. Proc Natl Acad Sci U S A 105(11): $4340-4345$

Gudmundsson J, Sulem P, Gudbjartsson DF, Blondal T, Gylfason A, Agnarsson BA, Benediktsdottir KR, Magnusdottir DN, Orlygsdottir G, Jakobsdottir M, Stacey SN, Sigurdsson A, Wahlfors T, Tammela T,

\section{ACKNOWLEDGEMENTS}

We are grateful to Heriberto Moran for technical assistance. This work was supported in part by the Society of Memorial SloanKettering Cancer Center (RJK); the Sharon Levine Corzine Cancer Research Initiative and the Kate and Robert Niehaus Clinical Cancer Genetics Initiative (KO); the Fonds de la Recherche en Santé du Québec (NH and WDF); and by a National Institutes of Health research grant to the International Consortium for Prostate Cancer Genetics (ICPCG). We are grateful to the NCI, and especially the CGEMS study team, for making their data available through dbGaP.
Breyer JP, McReynolds KM, Bradley KM, Saez B, Godino J, Navarrete S, Fuertes F, Murillo L, Polo E, Aben KK, van Oort IM, Suarez BK, Helfand BT, Kan D, Zanon C, Frigge ML, Kristjansson K, Gulcher JR, Einarsson GV, Jonsson E, Catalona WJ, Mayordomo JI, Kiemeney LA, Smith JR, Schleutker J, Barkardottir RB, Kong A, Thorsteinsdottir U, Rafnar T, Stefansson K (2009) Genome-wide association and replication studies identify four variants associated with prostate cancer susceptibility. Nat Genet 41(10): $1122-1126$

Gudmundsson J, Sulem P, Manolescu A, Amundadottir LT, Gudbjartsson D, Helgason A, Rafnar T, Bergthorsson JT, Agnarsson BA, Baker A, Sigurdsson A, Benediktsdottir KR, Jakobsdottir M, Xu J, Blondal T, Kostic J, Sun J, Ghosh S, Stacey SN, Mouy M, Saemundsdottir J, Backman VM, Kristjansson K, Tres A, Partin AW, Albers-Akkers MT, Godino-Ivan Marcos J, Walsh PC, Swinkels DW, Navarrete S, Isaacs SD, Aben KK, Graif T, Cashy J, Ruiz-Echarri M, Wiley KE, Suarez BK, Witjes JA, Frigge M, Ober C, Jonsson E, Einarsson GV, Mayordomo JI, Kiemeney LA, Isaacs WB, Catalona WJ, Barkardottir RB, Gulcher JR, Thorsteinsdottir U, Kong A, Stefansson K (2007a) Genome-wide association study identifies a second prostate cancer susceptibility variant at $8 \mathrm{q} 24$. Nat Genet 39: $631-637$

Gudmundsson J, Sulem P, Rafnar T, Bergthorsson JT, Manolescu A, Gudbjartsson D, Agnarsson BA, Sigurdsson A, Benediktsdottir KR, Blondal T, Jakobsdottir M, Stacey SN, Kostic J, Kristinsson KT, Birgisdottir B, Ghosh S, Magnusdottir DN, Thorlacius S, Thorleifsson G, Zheng SL, Sun J, Chang BL, Elmore JB, Breyer JP, McReynolds KM, Bradley KM, Yaspan BL, Wiklund F, Stattin P, Lindstrom S, Adami HO, McDonnell SK, Schaid DJ, Cunningham JM, Wang L, Cerhan JR, St Sauver JL, Isaacs SD, Wiley KE, Partin AW, Walsh PC, Polo S, Ruiz-Echarri M, Navarrete S, Fuertes F, Saez B, Godino J, Weijerman PC, Swinkels DW, Aben KK, Witjes JA, Suarez BK, Helfand BT, Frigge ML, Kristjansson K, Ober C, Jonsson E, Einarsson GV, Xu J, Gronberg H, Smith JR, Thibodeau SN, Isaacs WB, Catalona WJ, Mayordomo JI, Kiemeney LA, Barkardottir RB, Gulcher JR, Thorsteinsdottir U, Kong A, Stefansson K (2008) Common sequence variants on 2p15 and Xp11.22 confer susceptibility to prostate cancer. Nat Genet 40(3): 281-283

Gudmundsson J, Sulem P, Steinthorsdottir V, Bergthorsson JT, Thorleifsson G, Manolescu A, Rafnar T, Gudbjartsson D, Agnarsson BA, Baker A, Sigurdsson A, Benediktsdottir KR, Jakobsdottir M, Blondal T, Stacey SN, Helgason A, Gunnarsdottir S, Olafsdottir A, Kristinsson KT, Birgisdottir B, Ghosh S, Thorlacius S, Magnusdottir D, Stefansdottir G, Kristjansson K, Bagger Y, Wilensky RL, Reilly MP, Morris AD, Kimber CH, Adeyemo A, Chen Y, Zhou J, So WY, Tong PC, Ng MC, Hansen T, Andersen G Borch-Johnsen K, Jorgensen T, Tres A, Fuertes F, Ruiz-Echarri M, Asin L, Saez B, van Boven E, Klaver S, Swinkels DW, Aben KK, Graif T, Cashy J, Suarez BK, van Vierssen Trip O, Frigge ML, Ober C, Hofker MH, Wijmenga C, Christiansen C, Rader DJ, Palmer CN, Rotimi C, Chan JC, Pedersen O, Sigurdsson G, Benediktsson R, Jonsson E, Einarsson GV, Mayordomo JI, Catalona WJ, Kiemeney LA, Barkardottir RB, Gulcher JR, Thorsteinsdottir U, Kong A, Stefansson K (2007b) Two variants on chromosome 17 confer prostate cancer risk, and the one in TCF2 protects against type 2 diabetes. Nat Genet 39(8): 977-983

Haiman CA, Patterson N, Freedman ML, Myers SR, Pike MC, Waliszewska A, Neubauer J, Tandon A, Schirmer C, McDonald GJ, Greenway SC Stram DO, Le Marchand L, Kolonel LN, Frasco M, Wong D, Pooler LC, Ardlie K, Oakley-Girvan I, Whittemore AS, Cooney KA, John EM, Ingles SA, Altshuler D, Henderson BE, Reich D (2007) Multiple regions within 
$8 \mathrm{q} 24$ independently affect risk for prostate cancer. Nat Genet 39: $638-644$

Hooker S, Hernandez W, Chen H, Robbins C, Torres JB, Ahaghotu C, Carpten J, Kittles RA (2010) Replication of prostate cancer risk loci on $8 \mathrm{q} 24,11 \mathrm{q} 13,17 \mathrm{q} 12,19 \mathrm{q} 33$, and Xp11 in African Americans. Prostate 70(3): $270-275$

Kim ST, Cheng Y, Hsu FC, Jin T, Kader AK, Zheng SL, Isaacs WB, Xu J, Sun J (2010) Prostate cancer risk-associated variants reported from genome-wide association studies: meta-analysis and their contribution to genetic Variation. Prostate 70(16): 1729-1738

Kirchhoff T, Kauff ND, Mitra N, Nafa K, Huang H, Palmer C, Gulati T, Wadsworth E, Donat S, Robson ME, Ellis NA, Offit K (2004) BRCA mutations and risk of prostate cancer in Ashkenazi Jews. Clin Cancer Res 10(9): $2918-2921$

Klein RJ (2007) Power analysis for genome-wide association studies. BMC Genetics 8: 58

Mitchell MK, Gregersen PK, Johnson S, Parsons R, Vlahov D (2004) The New York Cancer Project: rationale, organization, design, and baseline characteristics. J Urban Health 81(2): $301-310$

Olshen AB, Gold B, Lohmueller KE, Struewing JP, Satagopan J, Stefanov SA, Eskin E, Kirchhoff T, Lautenberger JA, Klein RJ, Friedman E, Norton L, Ellis NA, Viale A, Lee CS, Borgen PI, Clark AG, Offit K, Boyd J (2008) Analysis of genetic variation in Ashkenazi Jews by high density SNP genotyping. BMC Genet 9: 14

Price AL, Butler J, Patterson N, Capelli C, Pascali VL, Scarnicci F, RuizLinares A, Groop L, Saetta AA, Korkolopoulou P, Seligsohn U, Waliszewska A, Schirmer C, Ardlie K, Ramos A, Nemesh J, Arbeitman L, Goldstein DB, Reich D, Hirschhorn JN (2008) Discerning the ancestry of European Americans in genetic association studies. PLoS Genet 4(1): e236

Prokunina-Olsson L, Fu YP, Tang W, Jacobs KB, Hayes RB, Kraft P, Berndt SI, Wacholder S, Yu K, Hutchinson A, Spencer Feigelson H, Thun MJ, Diver WR, Albanes D, Virtamo J, Weinstein S, Schumacher FR, Cancel-Tassin G, Cussenot O, Valeri A, Andriole GL, Crawford ED, Haiman CA, Henderson BE, Kolonel L, Le Marchand L, Siddiq A, Riboli E, Travis R, Kaaks R, Isaacs WB, Isaacs SD, Gronberg H, Wiklund F, Xu J, Vatten LJ, Hveem K, Kumle M, Tucker M, Hoover RN, Fraumeni Jr JF., Hunter DJ, Thomas G, Chatterjee N, Chanock SJ, Yeager M (2010) Refining the prostate cancer genetic association within the JAZF1 gene on chromosome 7p15.2. Cancer Epidemiol Biomarkers Prev 19(5): $1349-1355$

Purcell S, Neale B, Todd-Brown K, Thomas L, Ferreira MA, Bender D, Maller J, Sklar P, de Bakker PI, Daly MJ, Sham PC (2007) PLINK: a tool set for whole-genome association and population-based linkage analyses. Am J Hum Genet 81(3): 559-575

Robbins C, Torres JB, Hooker S, Bonilla C, Hernandez W, Candreva A, Ahaghotu C, Kittles R, Carpten J (2007) Confirmation study of prostate cancer risk variants at $8 \mathrm{q} 24$ in African Americans identifies a novel risk locus. Genome Res 17(12): 1717-1722

Shifman S, Johannesson M, Bronstein M, Chen SX, Collier DA, Craddock NJ, Kendler KS, Li T, O'Donovan M, O'Neill FA, Owen MJ, Walsh D, Weinberger DR, Sun C, Flint J, Darvasi A (2008) Genome-wide association identifies a common variant in the reelin gene that increases the risk of schizophrenia only in women. PLoS Genet 4(2): e28

Thomas G, Jacobs KB, Yeager M, Kraft P, Wacholder S, Orr N, Yu K, Chatterjee N, Welch R, Hutchinson A, Crenshaw A, Cancel-Tassin G, Staats BJ, Wang Z, Gonzalez-Bosquet J, Fang J, Deng X, Berndt SI, Calle EE, Feigelson HS, Thun MJ, Rodriguez C, Albanes D, Virtamo J, Weinstein S, Schumacher FR, Giovannucci E, Willett WC, Cussenot O, Valeri A, Andriole GL, Crawford ED, Tucker M, Gerhard DS, Fraumeni Jr JF., Hoover R, Hayes RB, Hunter DJ, Chanock SJ (2008) Multiple loci identified in a genome-wide association study of prostate cancer. Nat Genet 40(3): 310-315

Tian C, Plenge RM, Ransom M, Lee A, Villoslada P, Selmi C, Klareskog L, Pulver AE, Qi L, Gregersen PK, Seldin MF (2008) Analysis and application of European genetic substructure using $300 \mathrm{~K}$ SNP information. PLoS Genet 4(1): e4

Tischkowitz MD, Yilmaz A, Chen LQ, Karyadi DM, Novak D, Kirchhoff T, Hamel N, Tavtigian SV, Kolb S, Bismar TA, Aloyz R, Nelson PS, Hood L, Narod SA, White KA, Ostrander EA, Isaacs WB, Offit K, Cooney KA, Stanford JL, Foulkes WD (2008) Identification and characterization of novel SNPs in CHEK2 in Ashkenazi Jewish men with prostate cancer. Cancer Lett 270(1): $173-180$

Waters KM, Le Marchand L, Kolonel LN, Monroe KR, Stram DO, Henderson BE, Haiman CA (2009) Generalizability of associations from prostate cancer genome-wide association studies in multiple populations. Cancer Epidemiol Biomarkers Prev 18(4): 1285-1289

Yamada H, Penney KL, Takahashi H, Katoh T, Yamano Y, Yamakado M, Kimura T, Kuruma H, Kamata Y, Egawa S, Freedman ML (2009) Replication of prostate cancer risk loci in a Japanese case-control association study. J Natl Cancer Inst 101(19): 1330-1336

Yeager M, Chatterjee N, Ciampa J, Jacobs KB, Gonzalez-Bosquet J, Hayes RB, Kraft P, Wacholder S, Orr N, Berndt S, Yu K, Hutchinson A, Wang Z, Amundadottir L, Feigelson HS, Thun MJ, Diver WR, Albanes D, Virtamo J, Weinstein S, Schumacher FR, Cancel-Tassin G, Cussenot O, Valeri A, Andriole GL, Crawford ED, Haiman CA, Henderson B, Kolonel L, Le Marchand L, Siddiq A, Riboli E, Key TJ, Kaaks R, Isaacs W, Isaacs S, Wiley KE, Gronberg H, Wiklund F, Stattin P, Xu J, Zheng SL, Sun J, Vatten LJ, Hveem K, Kumle M, Tucker M, Gerhard DS, Hoover RN, Fraumeni Jr JF., Hunter DJ, Thomas G, Chanock SJ (2009) Identification of a new prostate cancer susceptibility locus on chromosome 8q24. Nat Genet 41(10): 1055-1057

Yeager M, Orr N, Hayes RB, Jacobs KB, Kraft P, Wacholder S, Minichiello MJ, Fearnhead P, Yu K, Chatterjee N, Wang Z, Welch R, Staats BJ, Calle EE, Feigelson HS, Thun MJ, Rodriguez C, Albanes D, Virtamo J, Weinstein S, Schumacher FR, Giovannucci E, Willett WC, Cancel-Tassin G, Cussenot O, Valeri A, Andriole GL, Gelmann EP, Tucker M, Gerhard DS, Fraumeni Jr JF., Hoover R, Hunter DJ, Chanock SJ, Thomas G (2007) Genome-wide association study of prostate cancer identifies a second risk locus at 8q24. Nat Genet 39: 645-649

Zheng SL, Hsing AW, Sun J, Chu LW, Yu K, Li G, Gao Z, Kim ST, Isaacs WB, Shen MC, Gao YT, Hoover RN, Xu J (2010) Association of 17 prostate cancer susceptibility loci with prostate cancer risk in Chinese men. Prostate 70(4): $425-432$

This work is published under the standard license to publish agreement. After 12 months the work will become freely available and the license terms will switch to a Creative Commons Attribution-NonCommercial-Share Alike 3.0 Unported License. 